\title{
PENGARUH PENGGUNAAN METODE DISCOVERY BERBASIS MEDIA REALITA TERHADAP HASIL BELAJAR MATA KULIAH KONSEP DASAR IPA 1
}

\author{
Idam Ragil Widianto Atmojo \\ PGSD FKIP Universitas Sebelas Maret \\ Jalan Slamet Riyadi 449 Surakarta \\ Email: idamragil@fkip.uns.ac.id
}

\begin{tabular}{|c|c|}
\hline ABSTRACT & ABSTRAK \\
\hline $\begin{array}{l}\text { This study aims to determine how much influence } \\
\text { the use of media-based discovery method's } \\
\text { realities of the learning outcomes over the course } \\
\text { Basic Concepts IPA } 1 \text { when compared to those } \\
\text { taught using direct instruction-based Power Point } \\
\text { (PPT). This research used the non-equivalent } \\
\text { control group design. Populations of this study } \\
\text { were all students of PGSD FKIP UNS second } \\
\text { semester of academic year 2013/2014. Cluster } \\
\text { Random Sampling is used in sampling. The data } \\
\text { analysis technique used is the prerequisite test } \\
\text { data analysis and hypothesis testing. For } \\
\text { prerequisite test, is including normality test with } \\
\text { Chi-square method and homogeneity test } \\
\text { methods Bartlett. Based on the analysis of t test } \\
\text { showed the } t \text { count> t table (3.599> } 2.001 \text { ), so } \\
\text { that HO is rejected. Thus there is a positive impact } \\
\text { on learning outcomes of the course the basic } \\
\text { concepts of science one-second semester } \\
\text { students are taught using methods of discovery- } \\
\text { based media reality. } \\
\text { Keywords: discovery, media reality, learning } \\
\text { outcomes, basic concepts IPA. }\end{array}$ & $\begin{array}{l}\text { Penelitian ini bertujuan untuk mengetahui } \\
\text { seberapa besar pengaruh penggunaan metode } \\
\text { discovery berbasis media realita terhadap hasil } \\
\text { belajar matakuliah Konsep Dasar IPA I apabila } \\
\text { dibandingkan dengan yang diajar } \\
\text { menggunakan pembelajaran langsung berbasis } \\
\text { power point (PPT). Desain penelitian yang } \\
\text { digunakan adalah non-equivalent control group } \\
\text { design. Populasi dari penelitian ini adalah seluruh } \\
\text { mahasiswa program studi PGSD FKIP UNS } \\
\text { semester II tahun akademik 2013/2014. Cluster } \\
\text { random sampling digunakan dalam } \\
\text { pengambilan sampel. Teknik analisis data yang } \\
\text { digunakan yaitu uji prasyarat analisis data dan uji } \\
\text { hipotesis. Untuk uji prasyarat meliputi uji } \\
\text { normalitas dengan metode chi-kuadrat dan uji } \\
\text { homogenitas dengan metode Bartlett. } \\
\text { Berdasarkan hasil analisis terhadap uji- } \dagger \text { diketahui } \\
\text { nilai thitung > ttabel (3,599 > 2,001), sehingga Ho } \\
\text { ditolak. Dengan demikian, terdapat pengaruh } \\
\text { positif terhadap hasil belajar matakuliah Konsep } \\
\text { Dasar IPA I mahasiswa semester II yang diajar } \\
\text { menggunakan metode discovery berbasis media } \\
\text { realita. } \\
\text { Kata Kunci: discovery, media realita, hasil } \\
\text { belajar, konsep dasar IPA. }\end{array}$ \\
\hline
\end{tabular}

How to Cite: Atmojo, I. (2015). PENGARUH PENGGUNAAN METODE DISCOVERY BERBASIS MEDIA REALITA TERHADAP HASIL BELAJAR MATAKULIAH KONSEP DASAR IPA 1. Mimbar Sekolah Dasar, 2(2), $130-139$. doi:http://dx.doi.org/10.17509/mimbar-sd.v2i2.1324.

PENDAHULUAN IImU Pengetahuan Alam (IPA) atau sekarang yang lebih dikenal dengan "sains" merupakan salah satu mata pelajaran wajib yang ada di sekolah dasar yang mempunyai peranan penting dalam kehidupan sehari-hari, karena IPA dapat melatih siswa untuk berpikir logis, rasional, kritis dan kreatif atau berpikir secara ilmiah. Dalam pembelajaran IPA, diperlukan keterampilan proses dari siswa untuk menemukan sejumlah konsepkonsep yang dipelajarai, sehingga peran aktif dari mahasiswa sangat dibutuhkan. Oleh karena itu, dalam mengajar, seorang guru harus menggunakan metode dan media yang tepat guna menumbuhkan 
Idam Ragil Widianto Atmojo, Pengaruh Penggunaan Metode Discovery...

minat belajar dan menciptakan pembelajaran IPA yang aktif dan menyenangkan bagi mahasiswa untuk mencapai tujuan perkuliahan berupa hasil belajar yang baik.

Saat ini masih banyak mahasiswa yang mengalami kesulitan dalam memahami konsep dari matakuliah IPA, karena kebanyakan dosen masih malas melaksanakan perkuliahan yang inovatif dengan memberi kesempatan serta kebebasan kepada mahasiswa untuk berpikir dan berkembang secara mandiri melalui penemuan dan proses berpikirnya sendiri sehingga dapat menumbuhkan keaktifan dan minat belajar mahasiswa. Seorang dosen tidak mau repot dengan apa yang akan diajarkan, mereka lebih memilih menggunakan jalan pintas dengan menggunakan pembelajaran langsung (direct instruction). Apabila kondisi seperti ini dibiarkan terus, maka akibatnya mahasiswa cenderung pasif dalam pembelajaran, kelas menjadi kurang efektif dan juga mengakibatkan rendahnya nilai yang diperoleh mahasiswa.

Salah satu metode pembelajaran yang cocok guna menumbuhkan pembelajaran IPA yang aktif adalah menggunakan metode discovery (penemuan) berbasis media realita (benda nyata). Metode ini memungkinkan mahasiswa terlibat secara aktif dalam mengikuti proses belajar-mengajar khususnya pada matakuliah Konsep Dasar IPA.

Anitah (2009, p. 55) mengatakan,

Belajar penemuan atau discovery
learning merupakan suatu
pembelajaran yang melibatkan
mahasiswa dalam pemecahan
masalah untuk pengembangan
pengetahuan dan ketrampilan.
Melalui penemuan, mahasiswa
belajar secara intensif dengan
mengikuti metode investigasi ilmiah
di bawah supervisi guru. Jadi belajar
dirancang, disupervisi, diikuti metode
investigasi.

Discovery (penemuan) merupakan suatu rangkaian kegiatan pembelajaran yang melibatkan secara maksimal seluruh kemampuan mahasiswa untuk mencari dan menyelidiki secara sistematis, kritis, dan logis sehingga mereka dapat menemukan sendiri pengetahuan, sikap, dan keterampilan sebagai wujud adanya perubahan perilaku (Hanafiah \& Suhana, 2009, p. 77).

Dalam pembelajaran, mahasiswa biasanya hanya menerima apa yang disampaikan oleh guru tanpa ada peran serta secara aktif untuk menemukan sejumlah konsep yang dipelajarinya. Metode discovery (penemuan) ini dapat mendorong mahasiswa untuk turut serta aktif dalam pembelajaran dengan menemukan sendiri suatu permasalahan untuk dipecahkan dan menciptakan situasi pembelajaran yang benar-benar menyenangkan. Sedangkan selain sebagai sumber belajar dan sebagai sarana penunjang kegiatan 
pembelajaran, media realita (benda nyata) dalam pembelajaran IPA juga dapat bermanfaat untuk membangkitkan keinginan dan minat belajar dari mahasiswa, membangkitkan motivasi dan rangsangan dalam kegiatan belajar serta membawa pengaruh dan memperluas pengetahuan dalam pembelajaran, sehingga mahasiswa mendapatkan pembelajaran bermakna yang membekas diingatan mereka.

Alasan dipadukannya metode discovery dengan media realita (benda nyata) dalam pembelajaran karena metode discovery merupakan metode untuk "menemukan" bukan hanya sekadar "menyelidiki". "Menyelidiki" merupakan bagian dari "menemukan" yang dapat dilaksanakan dengan menggunakan percobaan atau tanpa menggunakan percobaan. Kegiatan "menemukan" tidak mungkin terlaksana hanya dengan membayangkan atau menyelidiki suatu hal tersebut, tetapi perlu adanya tindakan yang nyata untuk melakukan pengamatan dan percobaan untuk menemukan suatu hal tertentu. Dengan demikian, diperlukan alat bantu yang benar-benar ada dan nyata untuk menunjang penemuan-penemuan tersebut. Hal ini sesuai dengan kegiatan "menemukan" dalam pembelajaran IPA materi proses fotosintesis, yakni digunakannya media realita (benda nyata) sebagai alat bantu guna menunjang siswa dalam kegiatan penemuan suatu konsep, prinsip atau halhal tertentu dalam perkuliahan IPA.
Perpaduan antara metode discovery dan media realita dalam pembelajaran IPA tersebut diharapkan dapat berpengaruh positif terhadap semangat belajar, membangkitkan keinginan dan minat belajar mahasiswa, membangkitkan motivasi dan rangsangan dalam kegiatan be-lajar serta membawa pengaruh dan memperluas pengetahuan dalam pembelajaran. Dengan demikian, mahasiswa mendapatkan pembelajaran bermakna yang membekas di ingatan mereka karena telah turut serta aktif menemukan suatu konsep, prinsip atau hal-hal lain dalam pembelajaran IPA, agar tujuan dari perkuliahan dapat tercapai secara optimal. Nantinya dominasi dosen dalam pembelajaran (teacher-centered) cenderung akan hilang dan dosen hanya akan menjadi seorang media fasilitator di kelas dalam pembelajaran yang berpusat pada mahasiswa (student-centered).

Hanafiah \& Suhana (2009, p. 78), menyebutkan bebarapa langkah yang harus diperhatikan dalam metode discovery (penemuan), antara lain sebagai berikut.

1) Mengidentifikasi kebutuhan mahasiswa.

2) Seleksi pendahuluan terhadap konsep yang akan dipelajari.

3) Seleksi bahan atau masalah yang akan dipelajari.

4) Menentukan peran yang akan dilakukan masing-masing mahasiswa.

5) Mencek pemahaman mahasiswa terhadap masalah yang akan diselidiki dan ditemukan. 
Idam Ragil Widianto Atmojo, Pengaruh Penggunaan Metode Discovery...

6) Mempersiapkan setting kelas.

7) Mempersiapkan fasilitas yang diperlukan.

8) Memberikan kesempatan kepada mahasiswa untuk melakukan penyelidikan dan penemuan.

9) Menganalisis sendiri atas data temuan.

10) Merangsang terjadinya dialog interaktif antar mahasiswa;

11) Memberi penguatan kepada mahasiswa untuk giat dalam melakukan penemuan.

12) Memfasilitasi mahasiswa dalam merumuskan prinsip-prinsip dan generalisasi atas hasil temuannya.

\section{METODE}

\section{Desain dan Prosedur Penelitian}

Penelitian ini dilaksanakan di Program Studi Pendidikan Guru Sekolah dasar (PGSD) FKIP Universitas Sebelas Maret Surakarta. Subjek penelitian adalah mahasiswa semester ॥ tahun ajaran 2013/2014. Waktu pelaksanaan penelitian ini selama 6 bulan yaitu dari bulan Februari 2013 sampai dengan bulan Juli 2013.

Penelitian ini menggunakan metode kuasi eksperimen lquasi exsperimental research), karena tidak semua variabel dapat dikontrol. Penelitian ini menggunakan desain kelompok kontrol non-ekuivalen (non-equivalent control group design), dalam desain ini terdapat dua kelompok yang dipilih tidak secara random, kemudian diberi pretest untuk mengetahui keadaan awal adakah perbedaan antara kelompok eksperimen dan kelompok kontrol, kemudian kedua kelompok baik eksperimen maupun kontrol diberi perlakuan berupa model pembelajaran yang berbeda.

Populasi merupakan wilayah generalisasi yang terdiri atas objek/subjek yang mempunyai kualitas dan karakteristik tertentu yang ditetapkan oleh peneliti untuk dipelajari dan kemudian ditarik simpulan (Sugiyono, 2010, p. 117). Populasi dalam penelitian ini adalah seluruh mahasiswa PGSD FKIP UNS semester ॥ $2013 / 2014$. Sedangkan sampel adalah bagian dari jumlah dan karakteristik yang dimilik oleh populasi tersebut (Sugiyono, 2010 , p. 118). Sampel dalam penelitian ini adalah sebagian mahasiswa semester ॥ PGSD FKIP UNS yang diambil tiga kelas sebagai kelas kontrol, kelas eksperimen dan kelas ujicoba.

Sebelum instrumen penelitian dapat digunakan kepada sampel, maka diteliti terlebih dahulu kualitasnya melalui ujicoba. Dari hasil ujicoba, dihitung validitas, reliabilitas, daya beda, dan tingkat kesukaran soal. Validitas yang digunakan dalam penelitian ini adalah validitas butir soal. Rumus untuk mengukur validitas instrumen adalah rumus korelasi product moment yang dikemukakan oleh Pearson. Untuk menguji reliabilitas soal tes menggunakan rumus KR-20.

Teknik pengumpulan data yang digunakan dalam penelitian ini yaitu teknik observasi, dokumentasi, dan tes. Teknik 
analisis data dlakukan secara bertahap, dengan mula-mula melakukan uji asumsi. Uji asumsi yang dimaksud adalah pengujian normalitas distribusi data dan homogenitas variansinya (Minium, King, \& Bear, 1993; Maulana, 2015). Untuk selanjutnya dilakukan pengujian hipotesis dengan kaidah parametrik ataupun nonparametrik, sesuai keputusan hasil uji asumsi. Sebagai langkah awal dilakukan pretest untuk melakukan uji keseimbangan dengan menggunakan uji-t. Setelah diberi perlakuan, kemudian dilaksanakan posttest. Untuk uji normalitas menggunakan metode chi-kuadrat, uji homogenitas menggunakan uji Bartlett. Sedangkan untuk uji hipotesis mengenai perbedaan mean, digunakan uji-t.

Variabel bebas pada penelitian ini adalah metode discovery berbasis media realita untuk kelas eksperimen, dan model pembelajaran langsung (direct instruction) berbasis media power point untuk kelas kontrol. Sedangkan variabel terikatnya adalah hasil belajar matakuliah Konsep Dasar IPA 1.

\section{HASIL DAN PEMBAHASAN}

Berdasar hasil perhitungan uji validitas soal, diketahui bahwa nilai rtabel productmoment pada taraf signifikasi $5 \%$ dengan $n=42$ adalah 0,308 . Soal yang valid kriterianya adalah jika rhitung $>$ rtabel. Uji validitas instrumen tes ujicoba awal yang berbentuk pilihan ganda sebanyak 50 butir soal menunjukkan 33 soal valid dan 17 soal tidak valid. Hasil uji reliabilitas terhadap 50 soal ujicoba menggunakan KR-20 dengan n-42 pada taraf signifikasi 5\% diperoleh $r_{11}=0,765$. Karena $r_{11} \geq 0,7$ maka instrumen tes tersebut dapat disimpulkan reliabel. Untuk uji daya beda soal diketahui 15 soal dengan daya beda jelek, 4 soal dengan daya beda cukup baik, 6 soal dengan daya beda baik, dan 25 soal dengan daya beda baik sekali. Berdasar hasil uji indeks kesukaran terhadap 50 soal ujicoba tes, diperoleh 7 soal mudah, 40 soal sukar dan 3 soal sukar. Soal yang kesukarannya terlalu sukar atau terlalu mudah tidak dipakai atau perlu direvisi.

Dari uji validitas, uji reliabilitas, uji daya beda, dan uji tingkat kesukaran soal, maka da-pat disimpulkan bahwa terdapat 26 soal yang valid dan 24 soal yang masuk dalam kriteria tidak valid yaitu soal nomor $3,4,6,7,9,11,14,17,20,23,24,26,29,30$, $31,32,35,37,39,41,44,47,48$, dan soal nomor 50. Agar dapat dipakai lagi untuk mengetahui kemampuan kelompok eksperimen dan kontrol maka soal-soal yang tidak valid tersebut direvisi kembali.

Hasil pretest kelompok eksperimen dapat dideskripsikan pada Tabel 1 berikut:

\begin{tabular}{lccc}
$\begin{array}{l}\text { Tabel 1. Distribusi Frekuensi } \\
\text { Kelompok Eksperimen }\end{array}$ & Hasil Pretest \\
\hline No. & $\begin{array}{c}\text { Data Nilai } \\
\text { mahasiswa }\end{array}$ & F & Persentase \\
& $35-42$ & 3 & $9,38 \%$ \\
\hline 1 & $43-50$ & 6 & $18,57 \%$ \\
2 & $51-58$ & 9 & $28,13 \%$ \\
3 & $59-66$ & 8 & $25,00 \%$ \\
4 & &
\end{tabular}


Idam Ragil Widianto Atmojo, Pengaruh Penggunaan Metode Discovery...

\begin{tabular}{cccc}
5 & $67-74$ & 3 & $9,38 \%$ \\
6 & $75-82$ & 3 & $9,38 \%$ \\
\hline & Jumlah & 32 & $100,0 \%$ \\
\hline
\end{tabular}

\begin{tabular}{llll}
2 & $48-55$ & 5 & $16,67 \%$ \\
3 & $56-63$ & 9 & $30,00 \%$ \\
4 & $64-71$ & 7 & $23,33 \%$ \\
5 & $72-79$ & 5 & $16,67 \%$ \\
6 & $80-87$ & 2 & $6,67 \%$ \\
\hline & Jumlah & 30 & $100,0 \%$ \\
\hline
\end{tabular}

Berdasar data hasil pretest kelompok eksperimen, nilai terendah mahasiswa adalah 35, sedangkan nilai tertingginya adalah 80. Dari total hasil keseluruhan data diperoleh rata-rata nilai hasil pretest mahasiswa kelompok eksperimen adalah 57,25 .

Hasil pretest kelompok kontrol dapat dideskripsikan pada Tabel 2. Berdasar data hasil pretest kelompok kontrol, nilai terendah mahasiswa adalah 40, sedangkan nilai tertingginya adalah 85 . Dari total hasil keseluruhan data diperoleh rata-rata nilai hasil pretest mahasiswa kelompok eksperimen adalah 63,23.

Pada uji keseimbangan dengan uji-t, diketahui thitung adalah 0,217 dan ttabel adalah 2,00030 dengan DK $=t \quad \mathrm{t}<$ $-2,00030$ atau $t>2,00030$ dan $t$ hitung $=$ 0,215 atau $-2,00030<0,215<2,00030$. Hasil tersebut menunjukkan $\mathrm{H}_{0}$ diterima karena thitung berada di antara -2.00030 sampai 2.00030 dan bukan anggota daerah kritis. Dengan demikian, kedua sampel (eksperimen dan kontrol) tersebut dapat disimpulkan mempunyai kemampuan awal yang sama.

Tabel 2. Distribusi Frekuensi Hasil Pretest Kelompok Kontrol

\begin{tabular}{lccc}
\hline No. & $\begin{array}{c}\text { Data Nilai } \\
\text { mahasiswa }\end{array}$ & F & Persentase \\
\hline 1 & $40-47$ & 2 & $6,67 \%$
\end{tabular}

Uji keseimbangan diambil dari nilai pretest dari kelompok eksperimen dan kelompok kontrol, yang disajikan dalam Tabel 3.

Tabel 3. Hasil Uji Keseimbangan dengan Uji-†

\begin{tabular}{cccc}
\hline Kelompok & thitung & ttabel & Keterangan \\
\hline Eksperimen & 0,215 & 2,00030 & Ho diterima \\
dan Kontrol & & & \\
\hline
\end{tabular}

Berdasar data di atas, maka dilakukan uji normalitas hasil pretest menggunakan chikuadrat, hasil uji tersebut dideskripsikan pada Tabel 4.

Tabel 4. Hasil Uji Normalitas Nilai Pretest dengan Chi-kuadrat

\begin{tabular}{llcl}
\hline Kelompok & $X_{\text {hitung }}^{2}$ & $X_{\text {tabel }}^{2}$ & Keterangan \\
\hline Eksperimen & 3,657 & 7,815 & $H_{0}$ diterima \\
Kontrol & 0,595 & 7,815 & Ho diterima \\
\hline
\end{tabular}

Berdasar uji normalitas hasil pretest dengan chi-kuadrat $\left(X^{2}\right)$, untuk kelas eksperimen diperoleh $X^{2}$ hitung sebesar 3,657 dan $X^{2}$ tabel sebesar 7,815 . Kemudian untuk kelas kontrol $X^{2}$ hitung sebesar 0,595 dan $X^{2}$ tabel sebesar 7,815. Dengan demikian, dapat disimpulkan sampel dari kedua kelompok berasal dari populasi yang berdistribusi normal. Uji homogenitas hasil pretest dilakukan dengan uji Bartlett, yang selengkapnya dideskripsikan pada Tabel 5. 
Tabel 5. Hasil Uji Homogenitas Nilai Pretest dengan Uji Bartlett

\begin{tabular}{cccc}
\hline Kelompok & $\mathrm{X}^{2}$ hitung & $\mathrm{X}^{2}$ tabel & Keterangan \\
\hline Eksperimen & 0,0921 & 3,841 & $H_{0}$ ditolak \\
dan Kontrol & & & \\
\hline
\end{tabular}

Dari hasil uji homogenitas diperoleh Xhi-tung sebesar 0,0921 , dan $X^{2}$ tabel diketahui 3,841. Jadi dapat disimpulkan bahwa kedua populasi berasal dari populasi yang homogen karena $\mathrm{X}^{2}$ hitung $<\mathrm{X}^{2}$ tabel atau $0,0921<3,841$.

Setelah pemberian tindakan dengan menggunakan metode discovery berbasis media realita pada kelompok eksperimen dan model pembelajaran langsung (direct instruction) berbasis media power point pada kelompok kontrol, maka langkah selanjutnya adalah pengolahan data hasil posttest mahasiswa. Hasil posttest kelompok eksperimen dideskripsikan pada Tabel 6.

Tabel 6. Distribusi Frekuensi Hasil Posttest Kelompok Eksperimen

\begin{tabular}{lccc}
\hline No. & $\begin{array}{c}\text { Data Nilai } \\
\text { mahasiswa }\end{array}$ & $\mathrm{F}$ & Persentase \\
\hline 1 & $55-61$ & 3 & $9,4 \%$ \\
2 & $62-68$ & 4 & $12,5 \%$ \\
3 & $69-75$ & 8 & $25,0 \%$ \\
4 & $76-82$ & 8 & $25,0 \%$ \\
5 & $83-89$ & 5 & $15,6 \%$ \\
6 & $90-96$ & 4 & $12,5 \%$ \\
\hline & Jumlah & 32 & $100,0 \%$ \\
\hline
\end{tabular}

Berdasarkan data hasil posttest kelompok eksperimen, nilai terendah mahasiswa adalah 55, dan nilai tertingginya adalah 95. Dari keseluruhan data di atas, rata-rata nilai hasil posttest mahasiswa kelompok eksperimen adalah 76,38.

Hasil posttest IPA pada materi proses fotosintesis pada kelompok kontrol dapat dideskripsikan pada Tabel 7.

Tabel 7. Distribusi Frekuensi Hasil Posttest Kelompok Kontrol

\begin{tabular}{lccc} 
No. & $\begin{array}{c}\text { Data Nilai } \\
\text { Mahasiswa }\end{array}$ & F & Persentase \\
\hline 1 & $45-51$ & 2 & $6,7 \%$ \\
2 & $52-58$ & 4 & $13,3 \%$ \\
3 & $59-65$ & 8 & $26,7 \%$ \\
4 & $66-72$ & 6 & $20,0 \%$ \\
5 & $73-79$ & 6 & $20,0 \%$ \\
6 & $80-86$ & 4 & $13,3 \%$ \\
\hline & Jumlah & 30 & $100,0 \%$ \\
\hline
\end{tabular}

Dari data hasil posttest kelompok kontrol, nilai terendah mahasiswa adalah 45, dan nilai tertingginya adalah 85 . Dari keseluruhan data di atas, rata-rata nilai hasil posttest mahasiswa kelompok kontrol adalah 67,13 .

Berdasar data di atas, maka dilakukan uji normalitas hasil posttest menggunakan chi-kuadrat, hasil uji tersebut dideskripsikan pada Tabel 8. Berdasar uji normalitas hasil posttest dengan chi-kuadrat, untuk kelas eksperimen diperoleh $X^{2}$ hitung sebesar 2,488 dan $X^{2}$ tabel sebesar 7,815 . Untuk kelas kontrol $X^{2}{ }^{2}$ itung sebesar 2119 dan $X^{2}$ tabel sebesar 7,815. Dengan demikian, sampel dari kedua kelompok berasal dari populasi yang berdistribusi normal. 
Idam Ragil Widianto Atmojo, Pengaruh Penggunaan Metode Discovery...

Tabel 8. Hasil Uji Normalitas Nilai Posttest dengan Chi-kuadrat

\begin{tabular}{llcl}
\hline Kelompok & $x_{\text {hitung }}^{2}$ & $x_{\text {tabel }}^{2}$ & Keterangan \\
\hline Eksperimen & 2,488 & 7,815 & $H_{0}$ diterima \\
Kontrol & 2,119 & 7,815 & Ho diterima \\
\hline
\end{tabular}

Uji homogenitas hasil posttest dilakukan dengan uji Bartlett, selengkapnya dideskripsikan dalam Tabel 9.

Tabel 9. Hasil Uji Homogenitas Nilai Posttest dengan Bartlett

\begin{tabular}{cccc}
\hline Kelompok & $\mathrm{X}^{2}$ hitung & $\mathrm{X}^{2}$ tabel & Keterangan \\
\hline Eksperimen & 1,243 & 3,841 & $H_{0}$ ditolak \\
dan Kontrol & & & \\
\hline
\end{tabular}

Dari hasil uji homogenitas di peroleh Xhitung sebesar 1,243, dan $X^{2}$ tabel diketahui 3,841. Jadi dapat disimpulkan bahwa kedua populasi berasal dari populasi yang homogen karena diketahui $X^{2}{ }^{2}$ hitung $<X^{2}$ tabel atau $1,243<3,841$. Hasil uji hipotesis data dengan menggunakan uji-† dapat dilihat pada Tabel 10.

Tabel 10. Hasil Uji Hipotesis Menggunakan Uji-t

\begin{tabular}{cccc}
\hline Kelompok & thitung & tabel & Keterangan \\
\hline Eksperimen & 3,599 & 2,00030 & $H_{0}$ ditolak \\
dan Kontrol & & & \\
\hline
\end{tabular}

Pada uji hipotesis dengan uji- $\dagger$ di atas, thitung adalah 3,599 dan tabel adalah 2,00030, sehingga dapat disimpulkan bahwa terdapat pengaruh positif dari penggunaan metode discovery berbasis media realita terhadap hasil belajar IPA daripada yang diajar dengan menggunakan model pembelajaran langsung (direct instruction) berbasis media power point.

Berdasarkan hasil uji hipotesis dapat diketahui bahwa terdapat pengaruh positif dari penggunaan metode discovery berbasis media realita terhadap hasil belajar matakuliah Konsep Dasar IPA 1 materi proses fotosintesis jika dibandingkan dengan yang dijar dengan model pembelajaran langsung (direct instruction) berbasis media power point.

Sebelum perlakuan diberikan, kedua kelompok sampel diberikan tes awal (pretest) untuk mengetahui kemampuan awal masing-masing kelompok. Setelah data pretest terkumpul, dilakukan uji keseimbangan pada data hasil pretest tersebut. Hasil uji keseimbangan ini menunjukkan bahwa kedua sampel seimbang, atau kedua sampel memiliki kemampuan awal yang sama. Rata-rata nilai dari masing-masing kelompok pada mulanya juga hampir sama, bahkan bisa dikatakan lebih tinggi kelompok kontrol yaitu dengan nilai 63,23. Sedangkan kelompok eksperimen hanya memiliki ratarata nilai 57,25 .

Setelah kelompok eksperimen dan kontrol diberi perlakuan dan selanjutnya diberi tes akhir (posttest), hasil tes menunjukkan adanya perbedaan nilai dari kedua kelompok. Kelompok eksperimen memperoleh nilai yang cukup bagus dengan rata-rata nilai 76,38 . Sedangkan kelompok kontrol memperoleh rata-rata 
nilai 67,13. Hasil uji hipotesis dengan menggunakan uji-† juga menunjukkan bahwa $\mathrm{H}_{0}$ ditolak atau dengan kata lain terdapat pengaruh positif dari penggunaan metode discovery berbasis media realita jika dibandingkan dengan yang diajar dengan model pembelajaran langsung (direct instruction) berbasis media power point.

Illahi (2012, p. 47) mengemukakan tujuan utama penggunaan metode discovery dalam pembelajaran adalah sebagai berikut.

1. Untuk mengembangkan kreativitas.

2. Untuk mendapat pengalaman langsung dalam belajar.

3. Untuk mengembangkan kemampuan berpikir rasional dan kritis.

4. Untuk meningkatkan keaktifan anak didik dalam proses pembelajaran.

5. Untuk mendapat inovasi dalam proses pembelajaran.

Berdasarkan tujuan utama penggunaan metode discovery dari Illahi (2012) dan hasil dari penelitian ini, maka dapat dikatakan bahwa discovery sangatlah efektif untuk mata kuliah IPA. Hal ini sesuai dengan simpulan Glasson (dalam Santrock, 2009, p. 171) yang mengatakan, "Siswa-siswa di kelas ilmu pengetahuan alam dengan discovery learning yang berbasis aktivitas mendapatkan nilai lebih tinggi dalam tes prestasi ilmu pengetahuan alam daripada siswa-siswa dalam kelas ilmu pengetahuan dengan pengajaran secara langsung yang tradisional". Di atas semua itu, sebagaimana yang disintesis dari pemikiran Presseisen (2001), Arsyad (2005), yang juga diperkuat oleh Sujana (2005), bahwa upaya pendidik melalui serangkaian kegiatan yang inovatif dalam pembelajaran IPA khususnya, terlebih dengan menggunakan media, akan memiliki peluang yang lebih besar dalam menghasilkan capaian belajar peserta didiknya.

\section{SIMPULAN}

Berdasarkan hasil analisis data di atas, diperoleh simpulan bahwa penggunaan metode discovery berbasis media realita berpengaruh positif terhadap hasil belajar matakuliah Konsep Dasar IPA 1 mahasiswa semester II Program Studi PGSD FKIP UNS Surakarta tahun akademik 2013/2014 apabila dibandingkan dengan yang diajar dengan menggunakan model pembelajaran langsung (direct instruction) berbasis media power point. Hal ini dibuktikan dengan hasil uji hipotesis yang menunjukkan thitung $>$ tabel $(3,599>2,00$ 030).

\section{REFERENSI}

Anitah, S. (2009). Teknologi pembelajaran. Surakarta: Learning Resources Center FKIP UNS.

Arsyad, A. (2005). Media pembelajaran. Jakarta: Rineka Cipta.

Hanafiah, N. \& Suhana, C. (2009). Konsep strategi pembelajaran. Bandung: Refika Aditama. 
Idam Ragil Widianto Atmojo, Pengaruh Penggunaan Metode Discovery...

Illahi, M. T. (2012). Pembelajaran discovery strategy \& mental vocational skill. Yogyakarta: Diva Press.

Maulana, M. (2015). INTERAKSI PBLMURDER, MINAT PENJURUSAN, DAN KEMAMPUAN DASAR MATEMATIS TERHADAP PENCAPAIAN KEMAMPUAN BERPIKIR DAN DISPOSISI KRITIS. Mimbar Sekolah Dasar, 2(1), 1-20. doi:http://dx.doi.org/10.17509/mimbarsd.v2i1.1318.

Minium, E. W., King, B. M., \& Bear, G. (1993). Statistical reasoning in psychology and education (3rd edition). New York: John Wiley \& Sons, Inc.

Presseisen, B. Z. (2001). Thinking skills: meanings and models revisited. In A.L. Costa (Ed.). Developing minds: a resource book for teaching thinking (3rd edition), pp. 47-53. Alexandria, VA: ASCD.

Santrock, J.W. (2009). Psikologi pendidikan. Terj. Angelica, D. Jakarta: Salemba Humanika.

Sugiyono. (2010). Metode penelitian pendidikan. Bandung: Alfabeta.

Sujana, A. (2005). Pembelajaran inkuiri pada bahan kajian unsur transisi perioda keempat melalui kegiatan hands-on untuk meningkatkan hasil belajar. (Tesis). Program Pascasarjana Universitas Pendidikan Indonesia, Bandung: Tidak dipublikasikan. 